The World in the Long

Twentieth Century 



\section{THE WORLD IN THE LONG TWENTIETH CENTURY}

An Interpretive History

Edward Ross Dickinson 
University of California Press, one of the most distinguished university presses in the United States, enriches lives around the world by advancing scholarship in the humanities, social sciences, and natural sciences. Its activities are supported by the UC Press Foundation and by philanthropic contributions from individuals and institutions. For more information, visit www.ucpress.edu.

\section{University of California Press}

Oakland, California

(C) 2018 by The Regents of the University of California

Library of Congress Cataloging-in-Publication Data Names: Dickinson, Edward Ross, author.

Title: The world in the long twentieth century : an interpretive history / Edward Ross Dickinson.

Description: Oakland, California : University of California Press, [2017] | Includes bibliographical references and index. | Identifiers: LCCN 2017022061 (print) | LCCN 2017024015 (ebook) | ISBN 9780520960961 () | ISBN 9780520285552 (pbk. : alk. paper)

Subjects: LCSH: History, Modern—2oth century-Chronology. |

History, Modern-21st century. | World politics-2oth century. | World politics-21st century. | Globalization-Social aspects. |

Civilization-2oth century.

Classification: LCC D421 (ebook) | LCC D421 .D53 2017 (print) | DDC 909.82--dc23

Manufactured in the United States of America

$\begin{array}{llllllll}25 & 24 & 23 & 22 & 21 & 20 & 19 & 18\end{array}$

$\begin{array}{llllllllll}10 & 9 & 8 & 7 & 6 & 5 & 4 & 3 & 2 & 1\end{array}$ 
This book is dedicated to the memory of my father William Richard Dickinson

1931-2015

geologist, scholar, and good, keen, steady man. 
